Jurnal The Messenger, Vol. 11, No. 1A, Special Issue on the School of Multimedia Technology and Communication Postgraduate Symposium, pp. 111-120

P-ISSN: 2086-1559, E-ISSN: 2527-2810

DOI: $10.26623 /$ themessenger.v11i1A.832

\title{
The Role of Anonymity in the Flaming Activity on YouTube in Malaysia
}

\section{Peran Anonimitas dalam Aktivitas Flaming pada YouTube di Malaysia}

\author{
Revathy Amadera Lingam ${ }^{1}$, Norizah Aripin ${ }^{1}$ \\ ${ }^{1}$ School of Multimedia Technology and Communication, Universiti Utara Malaysia, \\ Sintok, Kedah, Malaysia \\ *Corresponding author, e-mail: revathylingamphd@gmail.com
}

\begin{abstract}
The term flaming refers to offensive language such as swearing, insults and hating comments. Anonymity renders an environment that encourages irresponsible acts by people to display offensive behaviors. The aim of this study is to examine the role of anonymity in the flaming activity in Malaysia. The Uses and gratification Theory was proposed in order to explain flaming and its relation to anonymity. In-depth interview was conducted with 10 flamers of YouTube and the data was analyzed thematically. The results concludes that most of the flamers kept their identity anonymous due privacy concerns and for the freedom of speech. The rest of the flamers used their real name as a form of publicity, identity defining and to boost their selfconfidence. This study contributes practically in the enrichment of the data on flaming for the concerning parties such as Malaysian Communications and Multimedia Commission, and Cyber Security Malaysia.
\end{abstract}

Keywords: YouTube, Anonymity, Flaming, Social Networking.

\begin{abstract}
Abstrak
Istilah flaming mengacu pada bahasa ofensif seperti bersumpah, menghina dan komentar membenci. Anonimitas menghasilkan lingkungan yang mendorong tindakan tidak bertanggung jawab oleh orang-orang dengan menampilkan perilaku ofensif. Tujuan dari penelitian ini adalah untuk menguji peran anonimitas dalam aktivitas flaming di Malaysia. 'Uses and Gratification Theory' diusulkan untuk menjelaskan tentang flaming dan hubungannya dengan anonimitas. Wawancara mendalam dilakukan dengan 10 flamer dari YouTube dan data dianalisis secara tematis. Hasilnya dapat disimpulkan bahwa sebagian besar pelaku flamer menjaga identitas mereka karena masalah privasi dan untuk kebebasan berbicara. Sebagian flamer lainnya menggunakan nama asli sebagai bentuk publisitas, identitas, dan untuk meningkatkan kepercayaan diri mereka. Studi ini memberikan kontribusi praktis dalam pengayaan data tentang flaming untuk pihak-pihak yang berkepentingan seperti 'Malaysian Communications and Multimedia Commission,' dan 'Cyber Security Malaysia.'
\end{abstract}

Kata Kunci: YouTube, Anonimitas, Flaming, Jejaring Sosial.

\section{Introduction}

YouTube has been the breeding place for online abuse and hate-speech. The number of 'trolls' and the rate of flames are increasing day by day to the point where it is almost impossible to find a video on YouTube without a flaming comment on it. Negativity on the Internet is a norm since its existence but in the recent time, the presence of hate-speech and online abuse is at its peak. The term flaming refers to offensive language such as swearing, insults and hating comments (Moor, P.J., Heuvelman \& Verleur, 2010). The Hacker's Dictionary defines flaming as to speak rapidly or incessantly on an uninteresting topic or with a patently ridiculous attitude'. Flaming was also defined as verbal attacks 
intended to offend either persons or organizations. However, the word 'flaming' was not defined in any top dictionaries such as Oxford Dictionary, Cambridge Advanced Learner's Dictionary and so on. The term was defined by scholars and researchers and is being mutually used up to date. In recent days, YouTube has been labelled as the number one website with the most number of flames (Khan, 2017).

First and foremost, anonymity is one of the major components of YouTube that leads one to flame. According to Aiken and Waller (2000) anonymity renders an environment that encourages all the irresponsible acts by people to display offensive behaviours. Anonymity refers to an environment that involves around with secrets, hidden identity and masked personalities where basically, 'the notion of anonymity is related to freedom from identification, secrecy and lack of distinction' (Scott \& Orlikowski, 2012). Most users of YouTube are anonymous and go with an anonymous name and a random avatar to represent them in their 'channel' page (Khan, 2017).

Anonymity is characterized by its 'un-identifiably' which generates through the removal of self- identifying elements such as name and address (Wallace, 1999). Anonymity has been one of the concerned topics since the presence of Internet and computer mediated communication and has been debated over decades. Scholars around the world had intensified the debate surrounding anonymity where some are for it and some are against it. Brazier (2004), pointed out that anonymity as must in a computermediated communication environment to preserve 'information piracy' while Levmore \& Nussbaum (2010), go against it by arguing that anonymity creates negative environment with hostility and juvenile levels of responsibility. This is most relatable to this study because anonymity is the root cause of one to flame in YouTube as their identity remains unknown to the other users.

Many debates on the presence of anonymity had been done before the millennium which was towards the end of 1990s where the issue of anonymity came to the concern as communication through internet started taking place tremendously. The scholars generally argued whether commercial Internet interests could 'civilize' the 'wildness' of the current Internet communication during that period.

Hoffman, Novak, and Peralta (1999) studied on egress the anonymous communication on the Internet to be more of a cooperative interaction. Froomkin (1999), argued on the legal standing of anonymity in the Internet and the World Wide Web while Marx (1999), questioned sociology aspects of visual anonymity on the Internet users. The technical composition of visual anonymity was studied by Wayner (1999), while Nissenbaum (1999), puts effort on defining and understanding anonymity. Allen and Land (1999) on the other hand expressed the different variations of anonymity across multiple contexts.

Flaming spins around with anonymity and its anonymous participants. The question is does anonymity really trigger flaming on the Internet? To answer this question, Reinig and Mejias (2004), did a study on the level of flaming and its criticalness in GSS (Group Support Systems)-supported discussions, and anonymity. The study was done on the flaming level of anonymous groups versus identified groups. A group of United States and Hong Kong under graduates' business students were gathered in a room of an English speaking Public University located in Hong Kong. About 1 to 8 participants were made into a group of 17 Hong Kong students and 22 United States students. Both groups were divided into identified and anonymous groups.

Jurnal The Messenger, Vol. 11, No. 1A, Special Issue on the School of Multimedia Technology and Communication Postgraduate Symposium, pp. 111-120 
This study by Reinig and Mejias (2004) was done based on two types of factors at the group level of analysis which is critical comments and flames. The results of the study show that identified groups generate more flame comments than anonymous groups and anonymous groups generated more critical comments compared to the identified groups in total. Reinig and Mejias (2004) quoted that, 'As users become more anonymous, they may focus less on the social norms of their groups.' The result predicted was not achieved in this study because of the overall setting of the place where the study was conducted. All the students were placed in the same room, so it could have been less anonymous and reduction in social context cues. Does this mean that reduction is non-verbal cues often causes flaming and bad behaviour?

According to Lea, Spears, and Watt (2007) reduction in physical and non-verbal cues does makes communication and behaviour to be more unswayed and impersonal with the presence of anonymity. Lea et al. (2007) had also addressed that anonymity has the tendency on how a person considers himself/herself when during a discussion forum in an anonymous situation. Three major issues finding has been identified in his study. The first issue evaluated the consequent upon visual anonymity on impersonal communication in contrast to depersonalized communications. Results show that even though individuals are task-focused but at the same time had more concern on how other people view them as a person. It also increased the tendency on recognizing themselves as a part of the group rather than seeing themselves as an individual. The first issue concludes that anonymity shifts individuality into seeing one as a member of any group that they are interacting with. This makes sense as users of YouTube often see themselves as a part of the group that they are commenting with.

The second issue that were discussed in Lea et al., (2007) study was on whether anonymous condition influences the perception and behaviour of an individual on social groupings such as immediate group and wider social categories such as race and nationality. The result indicates that anonymity is more influential to immediate group rather that wider social categories. This concludes that anonymity mainly reduces interpersonal cues which affect self-approach and others' perception in interacting with temporary groups rather than pre-existing social categories such as nationality and gender. This is very valid point for this study as commenting in YouTube particularly in a certain video requires the users to just focus on an issue at the time of commenting, hence putting themselves it an immediate group while commenting. This situation makes them more prone to be flaming as anonymity is more influential in an immediate group.

The third issue of Lea et al. (2007) evaluated the effects of behaviour and perceptions of participants of anonymity groups. The point was to investigate how one looks into another person or evaluate the self-perceptions under a full anonymous situation where the images or any identity of the participants are not being revealed to each other. When everyone is anonymous participant tend to have self-stereotyping where they group themselves into the group they are interacting with rather than seeing them as unique individuals. Most times, a participant of any particular group does not act negatively or express their views openly as they are afraid that they will be punished by other group mates. Therefore, the overall study that was conducted by Lea et al. (2007), proves that communications that happens online may not necessarily more impersonal than face-to-face communication. Group based Internet communications are seen to be moving together as a whole rather than seen as an individual when it is visually anonymous. 
This whole scenario is of social networks moving as a group can be related with this study because according to Moor, P. J., Heuvelman \& Verleur (2010), YouTube is a community. The participants eventually move in together and blend in with a group or categorize them as a community of something they are attached to. A basic example is being the fan of top celebrities of Hollywood such as Justin Bieber and naming themselves as 'Believers'. Same goes to being a fan to top YouTubers such as 'Superwoman' and calling themselves as 'The Super Team or Unicorns'. So, these fans move in together as a group and this bunch of people defends their celebrity by 'punishing' whoever that flames in their videos. For example, the fans comments 'haters back off' or simply flags or reports the flaming comments.

A recent study by Kwon and Gruzd (2017), on swearing behaviour n YouTube revealed that one of the reason for aggressive and emotional texts on YouTube is due to the fact that most of its users are anonymous. This study examined comments on the official Donald Trump's channel and proved that anonymity is also one of the reason for the users of YouTube to spread hostility on this site. Another study by Fernandez (2017) on the issue of racism on social media also proved that anonymity leads to hate-speech and also encourages racism. It was revealed that extremist communities uses YouTube as their platform to display negativity due to the low anonymity barrier of the site.

Anonymity is being reviewed in this study mainly because the prime reason for one to flame is because of the hidden identity of the user. When an account of a user appears anonymous, the tendency of the particular person to flame increases. More swearing, hate-speech and hostility is displayed due to the absence of one's identity.

Most YouTube related studies that used UG as the theory, used quantitative as their method of study. Contrary to that, this study focuses on qualitative method which uses interview as its method. This study contributes to the usage of UGT in a new perspective which is gratification sought through negativity (flaming). This study also contributes practically in the enrichment of the data on flaming for the concerning parties such as Malaysian Communications and Multimedia Commission, and Cyber Security Malaysia.

\section{Methodology}

Qualitative research method involves process such as rising inquiries and systems, data gathered in the participant's setting, information examination inductively assembling from particulars to general themes, and the researcher making interpretations of the significance of the information (Creswell \& Poth, 2017). The final written report is structurally flexible depending on the outcome of the data interpreted which is also one of the benefits of the qualitative research method (Creswell \& Poth, 2017).

In-depth interviews were done for this study which includes intensive individual interview or meeting with a limited number of participants to explore their points of view on a specific thought, situation or circumstance (Boyce \& Neale, 2006). Face-to-face interviews was conducted after a mutual agreement on the venue and date. This technique empowers to produce factual data, participants' assessments, preferences, attitudes and other supportive data turning out amid the discussion with informants.

Along these lines, up close and personal interview method guarantees the quality of the answers and expands the response rate (Duncan \& Fiske, 2015). The population of this study is those who comments negatively on YouTube's comments' section whom better known as flamers or trolls. The 'flamers' were identified through the comments' section of YouTube. Flamers were chosen through YouTube comment section in

Jurnal The Messenger, Vol. 11, No. 1A, Special Issue on the School of Multimedia Technology and Communication Postgraduate Symposium, pp. 111-120 
Malaysian themed recent YouTube videos using purposive sampling. They were then messaged privately to their YouTube inbox asking for a face-to-face interview session.

The criteria of a flamer in this study is anyone who comments negatively on YouTube despite the number of times he/she has flamed online. According to Mason (2010), the minimum sample size to achieve saturation point suggests a number of 10 respondents of interview to obtain a valid data. Other reasons for choosing 10 respondents are due to the fact that different individual has different point of view and also to obtain a variety of answers on this issue and avoid biasness. Since the in-depth interview method will be implemented in this study, the method only requires a small number of informants (Guion, Diehl, \& McDonald, 2011).

This study also selects its informants using purposive sampling method. Purposive sampling method is chosen in view of attributes and a specific characteristics of a population that are in line with the goal of the research. Purposive sampling is otherwise called judgmental, specific, or subjective sampling (Sekaran \& Bougie, 2016). Purposive sampling method enabled the researcher to make selection for the most productive and right respondents according to the requirements of this study and they were contacted for an interview session.

The types of purposive sampling applied in this study were the homogeneous sampling method. Homogeneous sampling is the type of sampling method that focuses on candidates/population of study that shares similar characteristics, behaviours, acts (Etikan, Musa, \& Alkassim, 2016). The idea is to focus on this precise similarity and how it relates to the topic being researched. As for this study, the population of study are the flamers who flames on YouTube who also happen to have the negative personality traits which is through the display of hostility on online forums, especially YouTube.

The thematic analysis technique is used for analyzing the data for this study. The thematic analysis is done through line-by-line coding on the findings and the researcher gathered data through brief ideas of the information obtained (Creswell, 2007). This study questions on the role of anonymity in the act of flaming on YouTube videos in Malaysia.

Validity, according to Kirk and Miller (1986), is an issue that relies upon the observation, interpretation of the perceptions by the researcher. It was fundamental for the researcher to pick up acknowledgment and agreements of the different forms of qualitative research and to centre around the suitable research strategies (Silverman, 2016). The validity of this research was made sure in the in-depth interview through confront the informants of the study. The informants were sent the transcript of the interview session held through e-mail and they were requested to check if the interview transcript were coded verbatim, word-by-word. This was to ensure that there were no changes made in the process of transcription and in order to justify the validity aspects of this study.

Considering the privacy of every interviewee, the data collected and all the information gathered through the interview session were kept confidential at all times. The informants were assured that none of them will be identified or addressed by name at any time during this research. Creswell (2012), stressed that any sort of maltreatment such as, psychological, social, economic, physical of the interviewee and interviewer that are involved in the research is to be prevented as a fundamental role of ethics in any research process.

The aim intended in this study to understand the role of anonymity in the use of YouTube by Malaysians, thus the theory proposed is the Uses and Gratifications Theory (UGT). UGT is a theory which explains why and how people use certain media to gratify 
their needs and desires (Blumer \& Katz, 1974). Ultimately, the UGT is a theoretical framework that is treated to be one of the most appropriate frameworks that explain both psychological and behavioral propensities of a person in a computer-mediated communication (Lin, 1999).

For this study, this aspect suits best to explain the psychological thinking and the behaviors of those who uses YouTube and those who indulge themselves in the act of flaming. Since the theory questions on what people do with media, and looks into both behavior and psychology part of a person, it is best used to explain the phenomena of flaming in the context of the willingness of one to reveal their identity on this site.

\section{Results and Discussion}

Identity revelation in social media has always been a choice for every user. The participants of the online world can choose to either keep themselves anonymous or reveal their identities. A condition or character with respect to whom or what a thing is; the characteristics, convictions, and anything that recognize or distinguish a person or a thing (Olins, 2017). According to Fearon (1999), identity explained in two ways, in which social category and personal identity, which is directly proportional to online discourse activities where both social aspects and individuality matters.

'In the former sense, an 'identity' refers simply to a social category, a set of persons marked by a label and distinguished by rules deciding membership and (alleged) characteristic features or attributes. In the second sense of personal identity, an identity is some distinguishing characteristic (or characteristics) that a person takes a special pride in or views as socially consequential but more-or-less unchangeable.'

As for YouTube, the users need to be registered and needs to complete a login process in order to create an account on the site. The users must provide a name and valid email address for the process. Certain users even upload an image or an avatar that represents them. Anonymity has always been a popular issue of discussion on any online forums. Therefore, the researcher had asked the question of whether the name used in their YouTube account real or anonymous. The following are the transcripts of those who prefer to keep their image and identity hidden.

"No. Obviously not because I don't want to reveal myself when I do flaming comment. And I ... Ya. It is like ... For you to comment freely, you need to have to have some privacy. You cannot reveal yourself and write flaming comment on the video. And hiding my identity gives me a freedom to comment flaming type of comments", (Informant 1). "Not my real name because I don't want people to know who I am. I can express "my freely without fear" (Informant 3). "No. Not my real name because of privacy issues" (Informant 5). "I don't want others know who I am. This will make me easy to comment whatever I want. No one can find me. Or track me" (Informant 7). "No. it's not. I think it's privacy to put your real name there. It's easily to search for my name after that if someone wants to search" (Informant 8). "Not my real name. I don't prefer to reveal my identity" (Informant 10).

According to the majority answers of the informants above, anonymity has been a major part or reason for them to comment maliciously on YouTube. This is solely due to the anonymity reasons where their identity kept hidden.

This can be proved by the study that has been done by Kwon and Gruzd (2017) where a study was done on a set of YouTube videos based on Donald Trump's campaign channel. This study investigates whether forceful comments and swearing on YouTube

Jurnal The Messenger, Vol. 11, No. 1A, Special Issue on the School of Multimedia Technology and Communication Postgraduate Symposium, pp. 111-120 
content is in fact infectious and contagious. The result of this research affirms that swearing is not solely a result of an individual discourse and speech tendency but also a spreadable social practice that involves anonymity. This study confirms that anonymity plays an important role in aggression level portrayed on social media especially on YouTube.

Another study by Khan (2017) done on user participation and consumption level of YouTube. This study involves a sample of 1143 users of YouTube where it revealed that anonymity is one of the major cause of negativity displayed on the site. This also supports the idea of privacy online and freedom of speech of those who performed hostility online, similar to the answers to the informants above. This provides justifications on why most users prefer to be anonymous when it comes to interacting and commenting on social media sites.

The rest of the informants agreed of using the real name as their YouTube account username. The prefer allowing their names online simply for publicity, identity defining and due to self-confidence level. Their answers listed below:

"Yes it's my real name. Because I sign up account, and put up the videos of mine on YouTube. By that way I want people to notice me by my real name. I'm not just a commenter on YouTube; I also upload videos to YouTube. Now, when I become a grown up man so I feel like why hiding your name? Why faking your real username, like you making some other - for example, Animal Lover for example but now I feel like I'm mature enough so I can face it. Face the world. Face any hatred or any kind of predicaments so I feel like I can handle it. So, I use my real name" (Informant 2). "Yes, my real name. I don't think I should fake it. Since it's my account, it should be in my name and it should define my identity. So, why should I use a different name for that?" (Informant 4). "It is because I don't have any reasons for faking my name" (Informant 6). "It is because I feel that I don't unnecessarily comment irrelevant things. I make sure my comments are truly what I believe in and I don't feel the necessity in hiding my identity when commenting on any video Section" (Informant 9).

According to the informants above, revealing their actual name on YouTube is the right thing to do to retain their originality. As a term, it frequently conveys positive meanings - 'authentic' or realism can be characterized as 'adjusting to a unique in order to repeat fundamental elements' or 'not false or impersonation.' At the point when connected to identity, it inspires meanings of being 'consistent with one's own particular identity, soul, or character,' (Merriam-Webster, 2014). This proves that users with real name experiences self-confidence through identity defining on social media cites.

Haimson and Hoffmann (2016) suggested that on the web, realness' portraying nature reflected in the decisions users must make in regards to individual or enlightening divulgence. When rounding out online profiles or drawing in with others on the web, the online users must settle on decisions about uncovering or enabling access to subtle elements of one's life. These decisions speak to a sort of 'personal branding' that may seem to be genuine relying upon the setting of the revelations and the standards and affordability of a given site. These can be a factor on why certain users of YouTube need the access of YouTube for publicity and fame as related to the answers on Informant 2.

The answer provided by the informants on the issue of identity revelation concluded as a recap in the Figure 1 below: 


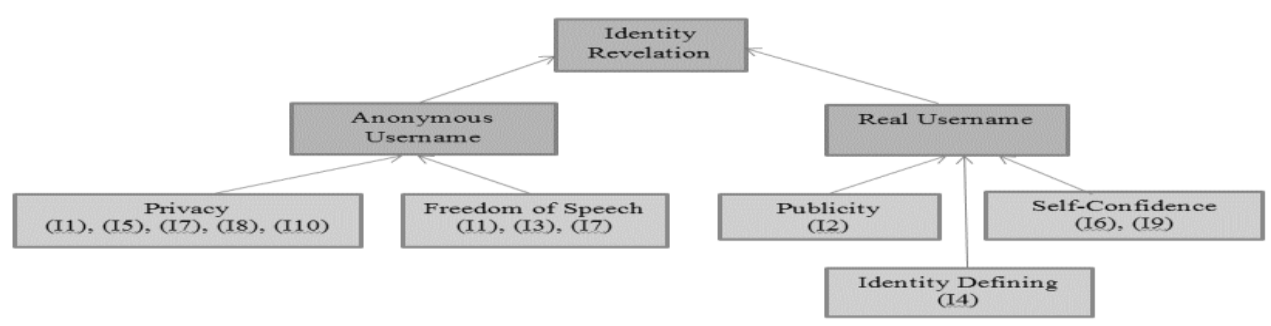

Figure 1. Identity Revelation Recap

\section{Conclusion}

The results of this study concludes that most of the flamers kept their identity anonymous due privacy concerns and for the freedom of speech. The rest of the flamers used their real name as a form of publicity, identity defining and to boost their selfconfidence. It is indeed a choice of the users of YouTube to whether or not to reveal their identity but in most cases anonymity do motivate flaming activities as it keeps their image hidden. In other cases, the flamers are more than happy to reveal their identity for satisfaction purposes which also supports the justification on the use of the uses and gratifications theory to explain this phenomenon.

YouTube has been a place for gaining satisfaction such as through watching talk shows and so on (Haqqu, Hastjarjo, \& Slamet, 2019). Through the outcome of this study, a different view on gratifications on usage of media has been identified through the usage of YouTube. Gratifications are now sought in an extreme way which includes negativity. Users of YouTube in Malaysia are revealed to have obtained gratifications and satisfaction through profanity as suggested by the outcome of this study. This can be considered as a contribution towards the development of this theory that includes a new angle which is negativity in the gratifications that users are looking for.

Considering practical contribution of this study, psychologically, the human minds tend to reflect whatever they see in their daily activities. From the act of flaming and by becoming 'keyboard warriors', peoples spread hatred by hating each other, hating other religions, other races and beliefs, other countries and this situation follows through. Whatever people see and read will affect them in both online and offline mode and chances are that hatred will be conveyed in their daily lives as a Malaysian and provokes conflict.

It is concluded that flaming in Malaysia is indeed a process. From the usage, thoughts, attitude, behaviour and finally commenting pattern, the flaming activity has been a typical culture of the local flamers. The aim of the flamers at the end of the day is to get gratified and to obtain satisfaction through hostility online. This is in line with the Uses and Gratifications theory used for this study which also agrees upon the idea of users of media to be an active participant and the media use is directed to goal. The medium used is also influenced by the use of other media and finally the value judgments of any media lies within the users themselves. Flaming is indeed is a choice of any flamers whether or not to keep indulging in it for self-satisfaction. With proper awareness and motivation, this awful activity can be reduced in any social media sites, including YouTube. In this point of time, even a simple hashtag can be used to convey a short message, live alone comments' sections (Mulyadi \& Fitriana, 2018).

Hopefully this study will also be an advantage for the government as it will provide data on how severe this problem really is. The government will then be able to implement

Jurnal The Messenger, Vol. 11, No. 1A, Special Issue on the School of Multimedia Technology and Communication Postgraduate Symposium, pp. 111-120 
new laws and policy for future YouTube users and gradually the act of flaming can be decreased. This study also may add relevance to the future data of Cyber Security Malaysia, MyCert, Malaysian Communications and Multimedia Commission and other concerning parties. It is also recommended that artificial intelligence to be used on YouTube in order to tackle to issue of anonymity.

\section{Acknowledgements}

The authors wish to thank the Ministry of Higher Education Malaysia in funding this study under the Fundamental Research Grant Scheme (FRGS) S/O Code 13594, and Research and Innovation Management Centre, Universiti Utara Malaysia, Kedah for the administration of this study.

\section{References}

Aiken, M., \& Waller, B. (2000). Flaming among first-time group support system users. Information \& Management, 37(2), 95-100.

Allen, J. P., \& Land, D. (1999). Attachment in Adolescence. In J. Cassidy \& P. R. Shaver (Eds.), Handbook of attachment: Theory, research, and clinical applications (pp. 319-335). New York: Guilford Press.

Blumer, J., \& Katz, E. (1974). The uses of mass communication. Beverley Hills, CA: Sage.

Boyce, C., \& Neale, P. (2006). Conducting in-depth interviews: A guide for designing and conducting in-depth interviews for evaluation input. Watertown: Pathfinder International.

Creswell, J. (2007). Qualitative inquiry and research design: Choosing among five approaches (2nd ed.). Thousand Oaks: Sage.

Creswell, J. (2012). Research design: Qualitative and quantitative approaches. Thousand Oaks: Sage.

Creswell, J., \& Poth, C. N. (2017). Qualitative inquiry and research design: Choosing among five approaches (2nd ed.). Thousand Oaks: Sage.

Duncan, S., \& Fiske, D. W. (2015). Face-to-face interaction: Research, methods, and theory (Vol. 3). Chicago: Routledge.

Etikan, I., Musa, S. A., \& Alkassim, R. S. (2016). Comparison of convenience sampling and purposive sampling. American Journal of Theoretical and Applied Statistics, $5(1), 1-4$.

Fearon, J. D. (1999). What is identity (as we now use the word). In Calif (Ed.), Unpublished manuscript. Standford: Stanford University.

Fernandez, A. (2017). Platformed racism: the mediation and circulation of an Australian race-based controversy on Twitter, Facebook and YouTube. Information, Communication \& Society, 20(6), 930-946.

Froomkin, M. A. (1999). Legal issues in anonymity and pseudonymity. Information Society, 15(2), 112-127.

Guion, L. A., Diehl, D. C., \& McDonald, D. (2011). Conducting an in-depth interview. University of Florida Cooperative Extension Service, Institute of Food and Agricultural Sciences, EDIS.

Haimson, O. L., \& Hoffmann, A. L. (2016). Constructing and enforcing "authentic" identity online: Facebook, real names, and non-normative identities. First Monday, 21(6).

Haqqu, R., Hastjarjo, S., \& Slamet, Y. (2019). Teenagers' Entertainment Satisfaction in 
Watching Talk Show Program through Youtube. Jurnal The Messenger, 11(1), 3845.

Hoffman, D. L., Novak, T. P., \& Peralta, M. A. (1999). Information privacy in the marketspace: Implications for the commercial uses of anonymity on the Web. The Information Society, 15(2), 129-139.

Khan, M. L. (2017). Social media engagement: What motivates user participation and consumption on YouTube? Computers in Human Behavior, 66, 236-247.

Kirk, J., \& Miller, M. L. (1986). Reliability and validity in qualitative research. California: Sage Publications Ltd.

Kwon, K. H., \& Gruzd, A. (2017). Is Aggression Contagious Online? A Case of Swearing on Donald Trump's Campaign Videos on YouTube. In 50th Hawaii International Conference on System Sciences.

Lea, M., Spears, R., \& Watt, S. E. (2007). Visibility and anonymity effects on attraction and group cohesiveness. European Journal of Social Psychology, 37(4), 761-773.

Levmore, S., \& Nussbaum, M. (2010). The offensive Internet: Speech, privacy, and reputation. Cambridge, MA: Harvard University Press.

Lin, C. (1999). Online-service adoption likelihood. Journal of Advertising Research, 39(2), 79-90.

Marx, G. (1999). What's in a name? Some reflections on the sociology of anonymity. Information Society, 15(2), 99-112.

Mason, M. (2010). Sample size and saturation in $\mathrm{PhD}$ studies using qualitative interviews. Forum Qualitative Sozialforschung/Forum: Qualitative Social Research, 11(3). Retrieved from http://nbn-resolving.de/urn:nbn:de:0114-fqs100387

Merriam-Webster. (2014). Authentic. Retrieved May 16, 2017, from http://www.merriam-webster.com/dictionary/authentic

Moor, P. J., Heuvelman, A., \& Verleur, R. (2010). Flaming on YouTube. Computers in Human Behavior, 26, 1536-1546.

Mulyadi, U., \& Fitriana, L. (2018). Hashtag (\#) as Message Identity in Virtual Community. Jurnal The Messenger, 10(1), 44-53.

Nissenbaum, H. (1999). The meaning of anonymity in an Information Age. Information Society, 15(2), 141-144.

Olins, W. (2017). The new guide to identity: How to create and sustain change through managing identity. Abingdon: Routledge.

Reinig, B., \& Mejias, R. (2004). The effects of national culture and anonymity on flaming and criticalness in GSS-supported discussions. Small Group Research, 35(6), 698723.

Scott, S., \& Orlikowski, W. (2012). Great expectations: The materiality of commensurability in social media. In P. M. Leonardi, B. Nardi, \& J. Kallinikos (Eds.), Materiality and organizing: Social interaction in a technological world (pp. 113-133). New York: Oxford University Press.

Sekaran, U., \& Bougie, R. (2016). Research methods for business: A skill building approach. United Kingdom: John Wiley \& Sons.

Silverman, D. (2016). Qualitative research. California: Sage Publications.

Wallace, K. . (1999). Anonymity. Ethics and Information Technology, 1, 23-35.

Wayner, P. (1999). Technology for anonymity: Names by other nyms. The Information Society, 15(2), 91-97.

Jurnal The Messenger, Vol. 11, No. 1A, Special Issue on the School of Multimedia Technology and Communication Postgraduate Symposium, pp. 111-120 